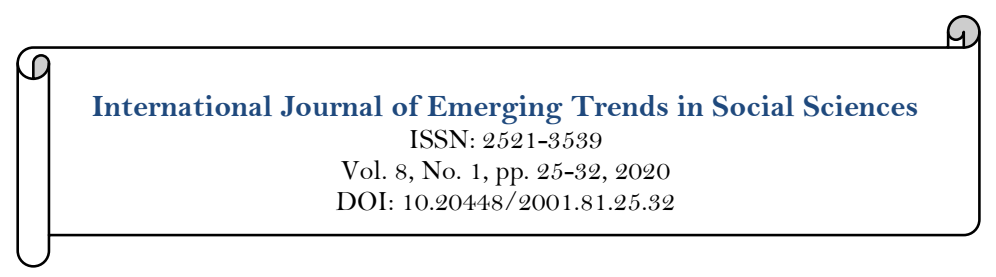

\title{
Antecedents of Firm’s Performance: A Conceptual Model
}

\author{
Liu Hailiang ${ }^{1 *}$ \\ Sara Ravan Ramzani ${ }^{2}$ \\ Hou Cheng Long ${ }^{3}$
}

${ }^{1, s}$ PhD Candidate, Post Graduate Centre-PGC, Limkokwing University of Creative Technology-LUCT, Selangor Malaysia.

${ }^{2}$ Email:imran_rana77@hotmail.com

-Senior Lecturer, Post Graduate Centre-PGC, Limkokwing University of Creative Technology-LUCT, Selangor Malaysia.

\begin{abstract}
This paper has been remained as evidence from the creative industry of China where it builds a conceptual framework on antecedents of organizational performance. A systematic literature review was conducted to study the possible antecedents of the performance. It found a number of factors that affect the performance of the creative Chinese industry; the major focus was on absorptive capacity, entrepreneurial orientation and market orientation. The study provides a conceptual framework, to elaborate the combination with a significant effect on performance of the firms and it is a unique contribution to literature and practice.
\end{abstract}

Keywords:

Entrepreneurial orientation Market orientation

Performance

Absorptive capacity.

Licensed:

This work is licensed under a

Creative Commons Attribution 4.0

License.

Publisher:

Scientific Publishing Institute

Accepted: 24 December 2019

Published: 7January 2020

Funding: This study received no specific financial support.

Competing Interests: The authors declare that they have no competing interests.

\section{Introduction}

For building a sustainable industrial base to overcome economic problems related to the increasing unemployment rate and to reduce reliance on international architectural design consultants, design and architectural firms in Shanghai region appear to be one of the fundamental solutions says report by The Regional Development Strategy for Shanghai Region.

In China, industry is currently facing problems within the organization regarding the lack of working skills in employees, low organizational loyalty and language. A recent study revealed that there still are many problems in the organization such as the lack of liquidity, investment, cost of operation, procurement, increased turnover, ability to make profit, and marketing. Marketing plans and responsive Market Orientation rarely proved to be successful when applied because market promotion is used regardless of the needs and customers' desires. Especially, this marketing strategy is used during the low season but usually remains u successful because it is implemented without knowing the genuine needs and requirements of the customers.

External world cannot be controlled by the business, therefore as suggested by Appiah-Adu and Ranchhod (1998) they have look within themselves so that the tools and means of thriving in any difficult situation could be find. Market Orientation is one of such valuable internal resource which as recommended by Levitt (1960) aids them in operating their businesses more productively. Few of the researchers stated that the productivity stems from the organization having clearer ideas and better guidance to fulfill customers' needs. Tomášková and Kopfová (2010) supported this by saying that it in turn, helps managers to monitor external 
and internal elements when they implement the Market Orientation Concept. However Tan and Liu (2014) found the effect of responsive and proactive market orientation unclear the on business performance. The knowledge regarding influence can be expanded by bridging up the gap in the literature by applying the effect of both proactive and responsive market orientation on business performance.

Therefore the design and architectural industry needs to study market orientation thoroughly besides the business should have clear understanding of expressed and latent needs, with the intentions to manage the intangible resource for building up capabilities of organization as the main objective. Grant (1991) suggested that the building up of capabilities is a part of RBV in the organization that helps to get competition advantage. Barney (1991) accepts that market orientation is valuable to the organization even if it is intangible resource and not a physical thing yet it helps organization to enhance it abilities to identify the current and latent needs of customers and fulfilling them satisfactorily. Market orientation and business performance is a resource that has a potential to build up capability in the design and architectural industry because capability is a part of RBV that gives competitive advantage to the institutes.

As mentioned earlier, various studies (Carbonell \& Rodriguez, 2010; Julian, Mohamad, Ahmed, \& Sefnedi, 2014; Webster, Hammond, \& Rothwell, 2014) considered the market orientation as one of the tools within the organization to help executives support the improvement of business performance and create competitive advantage. But, Bodlaj (2012); Zhang and Duan (2010) found the invisibility of the relationship.

Various research scholars (Leisen, Lilly, \& Winsor, 2002) studied and suggested market orientation has a positive effect on performances and realized the significance of Market Orientation in businesses. However positive effect on a market orientation regarding business performance have not been directly stated by many studies like (Jiménez-Jimenez, Valle, \& Hernandez-Espallardo, 2008). Besides Langerak (2003) found no apparent proof that market orientation has influence upon business performance, carried out a quantitative analysis of 56 studies in 28 countries and found a connection between market orientation and performance. he further stated that despite the quite weak relationship, the market orientation is a determinant of company performance.

It is dire need that the role of other factors that help boost the connection should be clearly understood. A study conducted by Nafie, Nimran, Al Musadieq, and Suyadi (2014) in these lines found that the organizational performance is significantly affected by the internal factors of the organization. In this regard, researchers, found that culture in organizations is a key internal factor affecting the organizational performance aside from encouraging the performance with its superior type. As a company can use it to control the internal factor, such as labor gaining loyalty and adjustability from its employees so this can be a key to success and a significant key to improve its business performance. Schalk and Gudlaugsson (2009) considered that these internal factors may have a great affect on the business performance measures and are a very important moderator.

As discussed in this literature of investigation, there is no single empirical evidence for the presence of mercury receptors and practitioner product preferences regarding the relationship between MO and the commercially descriptive and experimental data, Atuahene-Gima, Slater, and Olson (2005). Therefore, as suggested by renowned researchers' moderator variable in the relationship between MO and business performance is added, to help better explain that responsive and proactive market orientation increases the business performance.

As stated earlier, organizational performance is influenced by market orientation and organizational culture. To bridge up the gaps in the literature role of organization culture in the relationship among responsive, proactive market orientation, and business performance, is scrutinized as a moderator. To cover existing theoretical gaps and practical issues, the synergistic effect of Market Orientation on hotel business performance and its moderated impact is studied in this empirical research.

The effect of EO on Design and architectural firms' innovation has been examined by utilizing RBV by many scholars to evaluate the direct and indirect effects of $\mathrm{EO}$ on technological innovation within these firms. In order to explain the relationship between EO, MO and product innovation, Boso, Cadogan, and Story (2012a) utilized the RBV. Findings of these studies revealed in competitive markets that utilization of EO and MO behaviors is indispensible for firms. In a study in Korea, Hong, Song, and Yoo (2013) used the RBV to predict the indirect effects of strategic orientation observed in EO and MO on new product success and found that in predicting the role of these two resources in new product performance, the RBV is applicable and effective.

The direct and indirect influence of Entrepreneurial Orientation (EO) on innovation is appreciated by many different studies. EO and firm performance were found linked with each other by some studies (Ramayah, Hafeez, \& Mohamad, 2016). While Messersmith and Wales (2013) associated EO to firm profitability and growth. Jones and Rowley (2011) found many conceptual models that need empirically to justify the presence of a association between EO and innovation within the design and architectural firms. But Hong et al. (2013) found no impact of EO on innovation.

The RBV has also been used by some scholars to predict the role of ACAP in innovation in the design and architectural firms' context. Mason-Jones and Towill (2016) for example reported that for obtaining innovation from external sources ACAP is a prerequisite capability. While the mediating role of ACAP on the 
relationship between knowledge acquisition and innovation capability within knowledge-intensive industries in Taiwan was discussed. Findings of their study proved the complete mediating role of ACAP. On the other hand Rhee, Park, and Lee (2010) studied the moderating effect of ACAP on the interrelationship of knowledge competency and its antecedents. From results it was concluded that firms' knowledge competencies based on resources that result in excellent performance can be strengthened by ACAP.

ACAP has been focused by some empirical studies in the context of customer-supplier relationships within the industrial sector. Moreover, to measure firms' innovation, many researchers (Kim, Zhan, \& Krishna Erramilli, 2011) have attempted to investigate the relationship between ACAP and firm performance or the relationship between competitive advantage and ACAP (Kim et al., 2011).

Literature review revealed a lot of abundance of research regarding the study of ACAP and its impact on organizational innovation, but still there exists some gap. Wang and Altinay (2012) have investigated the effect of ACAP on firms' innovation without looking at other factors, such as risk-taking; or the level of knowledge about customers or competitors and firms' innovativeness.

In addition to this marketing orientation (MO) is also considered as a continuous extension of entrepreneurial orientation (EO) behavior BY many reserchers, while Baker and Sinkula (2007) considered it as the behavior of EO to influence and be significantly associated with MO in Design and architectural firms. It is also found that firms with a low level of EO, consider MO and innovation very less. Several evidences for the synergistic effect between EO and MO on innovation in Chinese small firms were presented highlighted the findings.

Moreover, firm's capacity to combine and interpret knowledge from outside was conceived as a requisite antecedent of MO by Raju, Lonial, and Crum (2011). The market responsiveness is mostly affected by the level to which a firm has better capability to identify and assimilate externally generated knowledge rather than by a firm's capability in reconfiguring its prior knowledge to adapt to the market conditions, Kim et al. (2011).

Therefore to provide evidence and empirical understanding of antecedent factors that affects market orientation and organizational / business performance within the context of industrial design and architectural firms is aimed to explore by the current study. This study also attempts to bridge the knowledge gap in the role of specific resources and capabilities, like EO and ACAP, in promoting business performance. Moreover, whether MO plays a mediating role between ACAP, OI, EO and BP would be examined by the present study.

In the market organizational performance reflects the business's accomplishment. Chittithaworn, Islam, Keawchana, and Yusuf (2011) studied the factors affecting management and skills, business achievement, design and architectural natures. Services, customers and market, the method of running a business and coordination, resources and finance, strategy, and external environment of design and were various factors that have been studied in China. According to Chittithaworn et al. (2011) to reduce the risk of failure and increase opportunities for the attainment and to provide a notion of people's business onset by considering all factors is the major objective.

Majority of design architectural firms in Shanghai are small and medium enterprises and the significance of personnel development is hardly realized by the entrepreneurs. Thus, these design and architectural lagged behind in the development of mechanism development for continuous achievement of knowledge and additional skills for the management by their personnel specifically, in terms of the absorptive capability of design and architectural firms. Thus it is highlighted that the use of organizational innovative way of handling operations and technology is not been focused as per requirement. Most of the Shanghai based firm of design and architectural nature were unsuccessful in terms of organizational innovativeness regarding the personnel's development. These firms failed in the development of executives' and organizations' ability besides also lacked in enhancement of knowledge, exchange of information, teamwork, embedded system, authorization, accordance of technology and work, connection between information networks. To compete with competitors in the market they could enhance the innovative potential and capability as well as the result oriented operation. Therefore, it can be safely argued that the organizational innovativeness and growth of organization is related with the design and architectural enhancement for their future development.

Many studies such as Salim and Sulaiman (2011) had investigated the factors affecting the performance of design and architectural that used innovation for organizational growth, and proved that the growth has a significant impact on innovations. Therefore, in increasing the performance of design and architectural, growing and innovation played a crucial role. However the mediating effect of marketing orientation between the dimensions of growing and performance had been investigated and findings revealed that innovation act as a mediator between growing and performance of design and architectural firms. Preliminary studies have been conducted regarding growing organization in relation with the design and architectural firms. Besides very few studies have been conducted to identify the effect of growing organization dimensions on organizational innovativeness and performance in Chinese design and architectural firms. Present study therefore, aims to provide some empirical findings regarding the performance of design and architectural in Shanghai, China along with growing organization dimensions as well as organizational innovativeness. 


\section{Literature Review}

\subsection{Absorptive Capacity (ACAP) Concepts and Related Literature}

Sparrow, Tarkowski, Lancaster, and Mooney (2009) reported that external knowledge transfer has increasingly been receiving attraction of researchers for the last fifty years or so. The concept of absorptive capacity has emerged and has been used successfully in studies investigating knowledge transfer among organizations (Andersén \& Kask, 2012). According to Messinis and Ahmed (2013) theoretically, external knowledge transfer stems from the fields of organizational learning, knowledge management and dynamic capability. The concept demands for the realization and acquisition of knowledge. Further it is, highlighted the internal processes of learning experience and present actions from the organization.

The concept of absorptive capacity (ACAP) has been defined by scholars (Martinkenaite, 2012) as the capability to recognize, assimilate and apply external knowledge. But some findings twisted this concept and categorized ACAP structure into two dimensions, namely: potential ACAP and realized ACAP. The potential ACAP refers to the capability for knowledge acquisition and assimilation realized ACAP stands for the knowledge transformation and exploitation. The phase in which the transition from assimilation phase to transformation phase takes place is considered as a shift from potential ACAP to realized ACAP.

However, studies highlighted one of the main drawbacks of ACAP that only few attempts have been made to measure it the context other than R \& D. various researcher tested the work of Zahra and George (2002) and found it appropriate to explain the mechanism of ACAP. The dimensions proposed by Zahra and George's are followed by the present study. There have been a lot of debates on ACAP among scholars of different schools of thoughts. Hence taking Zahra and George's study and above discussions as the basis, the absorptive capacity (ACAP) is defined by the present study in these words. The absorptive capacity (ACAP) is a set of capabilities and qualifications of the firm with which acquires, assimilates, transforms and exploits external knowledge from external environment and integrates it with existing pool of knowledge to generate a dynamic capacity for innovation.

\subsection{Entrepreneurial Orientation Concepts and Related Literature}

For the first time in history the use of entrepreneurial organizational firm was appreciated by Mintzberg, but it was Miller and Friesen (1983) work about entrepreneurial firms that attracted the attention of scholars reported Wales, Gupta, and Mousa (2013). The firms' strategies that encircle some aspects of entrepreneurship of decision patterns, working methods and their managerial practices, exploitation of opportunities found in the market is described as Entrepreneurial orientation (EO), as proposed by Mahmood and Hanafi (2013). Entrepreneurship is significant to the performance of firms in terms of innovation (Farrukh, Lee, \& Shahzad, 2019; Farrukh., Chong, Mansori, \& Ravan, 2017), likewise EO could significantly be used as measure of the pathway by which a firm is structured and organized. Moreover entrepreneurship is a mean to improve the achievement of firm's resources that are based on knowledge for the discovery and exploitation of new opportunities. Thus, as stated by Al-Swidi and Mahmood (2012) EO underlies the process followed by the managers enabling firms to stay ahead of their competitors.

As found by many studies, the innovation and technological changes, industrial crisis, changes in demography and macroeconomics give rise to Entrepreneurial opportunities (EO). Al-Swidi and Mahmood (2012) EO is behaviour and beliefs of firm that emphasizes on the proactive acquisition of entrepreneurial opportunities and creating innovation. Certain strategies can be developed by entrepreneurial firms like observe the marketplace before rivals, target advanced market sections and first-initiative preferences. Further to this, they can have hold on channels of distribution and establishment of brand recognition and control the market. Hence, CEO has potential positive implications to the firms' operations and businesses and looking for novel opportunities constantly may be invaluable. However entrepreneurial firms can launch new products and technology to show performance and may be attributed as the engine of development.

\subsection{Market Orientation Concepts and Related Literature}

Peter Drucker explained that customers are the core factor that preserve and protect the organization for the first time in 1950s in his thesis in the context of market orientation (MO) reported Eris and Ozmen (2012). Celuch and Murphy (2010) contributed significantly, many conceptual frameworks were presented and empirical studies regarding MO have been proposed in literature and in the field of marketing this attracted the scholars like Zhang and Duan (2010). In literature two of these proposed frameworks, regarding MO are prominent approaches. First framework was presented by Kohli and Jaworski (1990). According to this MO is composed of three behavioural constructs: intelligence generation, intelligence dissemination and responsiveness. Several studies like (Zhang \& Duan, 2010) used this approach and found that MO promotes the organization over its frontiers and facilitates the gathering of information from the external environment and its dissemination to develop a good level of awareness to key players. However, It is impossible for an organization to develop MO without employee's real inclination, clear understanding and the ability to interact in market-oriented behaviours as proposed by Lings and Greenley (2010). In the same line (JiménezJimenez et al., 2008) added that the external orientation and conceptualization concentrated on cultural factors like customer focus, competitors' focus and inter-functional coordination is also essential to develop MO with 
employees. Both approaches have been thoroughly examined in terms of their reliability in large firms but are not of the consensus as to which dominates the other. Many attempts have been made to define MO by various studies.

As for as the present study is concerned, the Kohli and Jaworski's concept of behavioural attitude is employed to define $\mathrm{MO}$ as a process of gathering and sharing of substantial knowledge about buyers and competitors to get sustainable competitive advantage through superior customer value and continuous innovation processes. In the development of marketing concepts, the origin of market orientation played a vital role (Narver \& Slater, 1990). As mentioned by Esteban et al. (2002) the definitions of the marketing concepts were more focussed by the previous studies and ignoring the issues related with measurement.

\subsection{Organizational Performance Concepts and Related Literature}

The concept that an organization is perceived as an association of, human, physical, and capital resources to achieve a common objective is explained by Barney. (2002) as organizational performance. Organizational performance as described by Hamon (2003) indicates the limits that an organisation is capable to achieve its objectives. Robbins and Coulter (2002) explained that organizational performance of an organization can be assessed as to how efficiently and effectively it achieves its goals.

Andersen (2006) said that the term 'organizational performance' is interchangeable and synonymous with effectiveness. The notion of effectiveness can be considered as a ratio where two entities are required to measure and define effectiveness. The effectiveness can also be regarded as the degree of the achievement of goals. As indicated by Hancott (2005) various indicators have been selected since the mid-1900's in order to measure organizational performance. the criteria used to measure organizational performance have been expansion of market share, rate of growth of profits, net or total rate of growth of assets, financial return on sales, financial return to shareholders, net asset return, , increase in new products, etc. The measurement of organizational effectiveness can also be measured through financial, operational and behavioral means as suggested by Montanari, Morgan, and Bracker (1990).

Firstly, the scholars defined financial performance as the profitability and growth of an organization. Secondly, to determine the effectiveness of the work activity of organizations such as productivity, efficiency, resource acquisition, and employee reaction all operational activity can assist in evaluation. Thirdly, individual performance can be measured in terms of absence of strain, satisfaction, adaptability, development and open communication, which indicates behavioural effectiveness.

To measure organizational performance certain goals are set and to check the degree to which goals are achieved, various studies have highlighted different internal measures reported Bennis (1966) stated that organizational performance can be used to measure the organization health. Some researchers such as Schermerhorn, Hunt, and Osborn (2002) when assessing performance and examining the organizational relationship to its environment, highlighted external factors. The quality and quantity of the achievement of individuals or groups can be the indicator of performance as suggested by Schermerhorn et al. (2002). the capability of the organization to survive can be utilized to determine organizational performance, was proposed by Yuchtman and Seashore (1967). The capability of organization is defined as the ability of the organization to maintain its operations by utilizing its environment through acquiring limited and beneficial resources.

To measure organizational performance both financial and non-financial aspects are kept in view. Smith, Bracker, and Miner (1987) included return on investment (ROI), profit, growth in financial aspects and Chong (2008) added return on sales in this list. The financial measures of performance, such as sales and profit, may not clearly reflect the quality of the SMEs' performance was claimed by Bucklin and Sengupta (1993). The assessment of the performance presented by Chong (2008) should be made complementary as suggested by Orser, Hogarth-Scott, and Riding (2000) while analyzing effect on the non-financial aspects of various enterprises. The revenue per employee and the revenue generation per employee as suggested by Johannisson (1993) size of revenue growth (Haber \& Reichel, 2005) customer satisfaction (Chapman \& Shaw, 2001) market share (Bouchikhi, 1993) and workforce market share growth as suggested by O'Farell (1986).

The constant assessment is required for these aspects and in order to continue to be pertinent in a changing and competitive environment with fluctuating availability and variable costs of resources (McGee, Dowling, \& Megginson, 1995) fit into internal planning and target setting (Russell Merz \& Sauber, 1995) and responding to the requirements and demands of stakeholders (Srinivasan, Woo, \& Cooper, 1994) they need to be reviewed constantly.

\subsection{Significance of the Study}

- There is a gap in the present literature because of absence of a theoretical framework that could reflect the influence of entrepreneurial orientation and market orientations besides the combined effect of ACAP and MO. To gain organizational performance, Design and architectural firms will be benefitted if such a gap is filled.

- By producing a model based on confirmed behavioral factors it is hooped that current stud will make some contributions and the Design and architectural firms would be able to focus on both internal and external 
sources for knowledge gain. Moreover, it is hoped that the significant role of MO in mediating the relationship between study independent and dependent variables will be enhanced by the contribution of this study. Thus, a firm's innovative efforts would be balanced if both orientations are considered. The integrating effects of both ACAP and MO produce the second mechanism_ the responding and filtering mechanism because it is not sure that external knowledge about customers and markets can be utilized easily. There is a shift from learning to meet customers' current and potential needs for firms because of this mechanism.

- Further, the Design and architectural firms would be helped out to evaluate firm's performance and analyze the right segments of international customers hence, more efficient and pertinent plans and procedures based on their understanding of employees' attitudes towards their new products would be implemented

- $\quad$ The policy-makers, government agencies and industry of Design and architectural firms would be able to gain better understanding related to their problems with the help of current study specifically in their efforts to compete and survive in the industry.

- The in-depth knowledge on the nature of market orientation practiced in large-sized institutes in china will be provided by this research besides how business performance is influenced by the moderating effect of the organizational culture. The effect of the market orientation and organizational culture studied by this research makes the outcome of the study more valuable.

- In addition it assures the managers that by enhancing and building significant aspects in the organization such as marketing management or marketing plan this relationship can be achieved. Besides design and architectural firms, business operators and the government would be benefitted from the contribution of knowledge and understanding of this study and thus enabling the organization more the capable.

\section{References}

Al-Swidi, A. K., \& Mahmood, R. (2012). Total quality management, entrepreneurial orientation and organizational performance: The role of organizational culture. African Journal of Business Management, 6(13), 4717-4727. Available at: https://doi.org/10.5897/ajbm11.2016

Andersén, J., \& Kask, J. (2012). Asymmetrically realized absorptive capacity and relationship durability. Management Decision, 5o(1), 43-57. Available at: https://doi.org/10.1108/00251741211194868.

Andersen, J. A. (2006). Leadership, personality and effectiveness. The Journal of Socio-Economics, 35(6), 1078-1091. Available at: https://doi.org/10.1016/j.socec.2005.11.066.

Appiah-Adu, K., \& Ranchhod, A. (1998). Market orientation and performance in the biotechnology industry: An exploratory empirical analysis. Technology Analysis \& Strategic Management, 10(2), 197-210. Available at: https://doi.org/10.1080/09537329808524311.

Atuahene-Gima, K., Slater, S. F., \& Olson, E. M. (2005). The contingent value of responsive and proactive market orientations for new product program performance. Journal of Product Innovation Management, 22(6), 464-482. Available at: https://doi.org/10.1111/j.1540-5885.2005.00144.x.

Baker, W. E., \& Sinkula, J. M. (2007). Does market orientation facilitate balanced innovation programs? An organizational learning perspective. Journal of Product Innovation Management, 24(4), 316-334. Available at: https://doi.org/10.1111/j.1540-5885.2007.00254.x.

Barney, J. (1991). Firm resources and sustained competitive advantage. Journal of Management, 17(1), 99-120. Available at: $10.1177 / 014920639101700108$

Barney., J. B. (2002). Gaining and sustaining competitive advantage. Upper Saddle River, NJ: Prentice Hall.

Bennis, W. G. (1966). Changing organizations: Essays on the development and evolution of human organizations. New York: McGraw Hill.

Bodlaj, M. (2012). Do managers at two hierarchical levels differ in how they assess their company's market orientation? JEEMS Journal of East European Management Studies, 17(3), 292-312. Available at: https://doi.org/10.5771/0949-6181-2012-3-292.

Boso, N., Cadogan, J. W., \& Story, V. M. (2012a). Complementary effect of entrepreneurial and market orientations on export new product success under differing levels of competitive intensity and financial capital. International Business Review, 21(4), 667-681. Available at: https://doi.org/10.1016/j.ibusrev.2011.07.009.

Bouchikhi, H. (1993). A constructivist framework for understanding entrepreneurship performance. Organization Studies, 14(4), 549-570. Available at: https://doi.org/10.1177/017084069301400405.

Bucklin, L. P., \& Sengupta, S. (1993). Organizing successful co-marketing alliances. Journal of Marketing, 57(2), 32-46. Available at: https://doi.org/10.1177/002224299305700203.

Carbonell, P., \& Rodriguez, E. A. I. (2010). The effect of market orientation on innovation speed and new product performance. Journal of Business \& Industrial Marketing, 25(7), 501-513. Available at: https://doi.org/10.1108/08858621011077736.

Celuch, K., \& Murphy, G. (2010). SME internet use and strategic flexibility: The moderating effect of IT market orientation. Journal of Marketing Management, 26(1-2), 131-145. Available at: https://doi.org/10.1080/02672570903574296.

Chapman, G., \& Shaw, G. (2001). Performance measurement in organisational networks: An exploratory case study. International Journal of Business Performance Management, 3(1), 30-46. Available at: https://doi.org/10.1504/ijbpm.2001.000089. 
Chittithaworn, C., Islam, M. A., Keawchana, T., \& Yusuf, D. H. M. (2011). Factors affecting business success of small \& medium enterprises (SMEs) in Thailand. Asian Social Science, 7(5), 180-190. Available at: https://doi.org/10.5539/ass.v7n5p180.

Chong, H. G. (2008). Measuring performance of small-and-medium sized enterprises: The grounded theory approach. Journal of Business and Public Affairs, 2(1), 1-10.

Eris, E. D., \& Ozmen, O. N. T. (2012). The effect of market orientation, learning orientation and innovativeness on firm performance: A research from Turkish logistics sector. International Journal of Economic Sciences \& Applied Research, 5(1), 77-108.

Esteban, A., Anzueto, A., Frutos, F., Alía, I., Brochard, L., Stewart, T. E., . . Nightingale, P. (2002). Characteristics and outcomes in adult patients receiving mechanical ventilation: A 28-day international study. Jama, 287(3), 345-355. Available at: https://doi.org/10.1001/jama.287.3.345.

Farrukh, M., Lee, J. W. C., \& Shahzad, I. A. (2019). Intrapreneurial behavior in higher education institutes of Pakistan: The role of leadership styles and psychological empowerment. Journal of Applied Research in Higher Education, 11(2), 273-294.

Farrukh., M., Chong, W. Y., Mansori, S., \& Ravan, R. S. (2017). Intrapreneurial behaviour: The role of organizational commitment. World Journal of Entrepreneurship, Management and Sustainable Development, 13(3), 243-256. Available at: https://doi.org/10.1108/WJEMSD-03-2017-0016.

Grant, R. M. (1991). The resource-based theory of competitive advantage: Implications for strategy formulation. California Management Review, 33(3), 114-135. Available at: https://doi.org/10.2307/41166664.

Haber, S., \& Reichel, A. (2005). Identifying performance measures of small ventures- the case of the tourism industry. Journal of Small Business Management, 43(3), 257-286. Available at: https://doi.org/10.1111/j.1540627x.2005.00137.x.

Hamon, T. T. (2003). Organizational effectiveness as explained by social structure in a faith-based business network organization (Unpublished Doctoral Dissertation). Regent University, Virginia Beach, VA.

Hancott, D. E. (2005). The relationship between transformational leadership and organizational performance in the largest public companies in Canada (Unpublished Doctoral Dissertation). Capella University, Minneapolis, MN.

Hong, J., Song, T. H., \& Yoo, S. (2013). Paths to success: How do market orientation and entrepreneurship orientation produce new product success? Journal of Product Innovation Management, 30(1), 44-55. Available at: https://doi.org/10.1111/j.1540-5885.2012.00985.x.

Jiménez-Jimenez, D., Valle, R. S., \& Hernandez-Espallardo, M. (2008). Fostering innovation: The role of market orientation and organizational learning. European Journal of Innovation Management, 11(3), 389-412. Available at: https://doi.org/10.1108/14601060810889026.

Johannisson, B. (1993). Designing supportive contexts for emerging enterprises, in C. Karlsson, B. Johannisson, and D. Storey (eds.), Small Business Dynamics: International, National and Regional Perspectives. London: Routhledge.

Jones, R., \& Rowley, J. (2011). Entrepreneurial marketing in small businesses: A conceptual exploration. International Small Business Journal, 29(1), 25-36. Available at: https://doi.org/10.1177/0266242610369743.

Julian, C. C., Mohamad, O., Ahmed, Z. U., \& Sefnedi, S. (2014). The market orientation-performance relationship: The empirical link in export ventures. Thunderbird International Business Revierw, 56(1), 97-110. Available at: https://doi.org/10.1002/tie.21598.

Kim, C., Zhan, W., \& Krishna Erramilli, M. (2011). Resources and performance of international joint ventures: The moderating role of absorptive capacity. Journal of Asia Business Studies, 5(2), 145-160. Available at: https://doi.org/10.1108/15587891111152311.

Kohli, A. K., \& Jaworski, B. J. (1990). Market orientation: the construct, research propositions, and managerial implications. Journal of Marketing, 54(2), 1-18. Available at: https://doi.org/10.2307/1251866.

Langerak, F. (2003). An appraisal of research on the predictive power of market orientation. European Management Journal, 21(4), 447-464. Available at: https://doi.org/10.1016/s0263-2373(03)00073-2.

Leisen, B., Lilly, B., \& Winsor, R. D. (2002). The effects of organizational culture and market orientation on the effectiveness of strategic marketing alliances. Journal of Services Marketing, 16(3), 201-222. Available at: https://doi.org/10.1108/08876040210427209.

Levitt, T. (1960). Marketing myopia. Boston.

Lings, I. N., \& Greenley, G. E. (2010). Internal market orientation and market-oriented behaviours. Journal of Service Management, 21(3), 321-343. Available at: https://doi.org/10.1108/09564231011050788.

Mahmood, R., \& Hanafi, N. (2013). Entrepreneurial orientation and business performance of women-owned small and medium enterprises in Malaysia: Competitive advantage as a mediator. International Journal of Business and Social Science (IJBSS), 4(1), 82-90.

Martinkenaite, I. (2012). Antecedents of knowledge transfer in acquisitions. Baltic Journal of Management, 7(2), 167-184. Available at: https://doi.org/10.1108/17465261211219796.

Mason-Jones, R., \& Towill, D. (2016). Open innovation in SMEs: A systematic literature review. Int $J$ Logistics Management, 9(1), 58-73.

McGee, J. E., Dowling, M. J., \& Megginson, W. L. (1995). Cooperative strategy and new venture performance: The role of business strategy and management experience. Strategic Management Journal, 16(7), 565-580. Available at: https://doi.org/10.1002/smj.4250160706.

Messersmith, J. G., \& Wales, W. J. (2013). Entrepreneurial orientation and performance in young firms: The role of human resource management. International Small Business Journal, 31(2), 115-136. Available at: $10.1177 / 0266242611416141$.

Messinis, G., \& Ahmed, A. D. (2013). Cognitive skills, innovation and technology diffusion. Economic Modelling, 30, 565578. Available at: https://doi.org/10.1016/j.econmod.2012.10.002. 
Miller, D., \& Friesen, P. H. (1983). Strategy-making and environment: The third link. Strategic Management Journal, 4(3), 22 1-235. Available at: https://doi.org/10.1002/smj.4250040304.

Montanari, J. R., Morgan, C. P., \& Bracker, J. (1990). Strategic management: A choice approach. Orlando: The Dryden Press.

Nafie, L. N., Nimran, U., Al Musadieq, M., \& Suyadi, I. (2014). Organizational internal factors, corporate entrepreneurship, and organizational performance. European Journal of Business and Management, 6(36), 83-97.

Narver, J. C., \& Slater, S. F. (1990). The effect of a market orientation on business profitability. Journal of Marketing, 54(4), 20-35. Available at: https://doi.org/10.2307/1251757.

O'Farell, P. (1986). The nature of new firms in Ireland: Empirical evidence and policy implications, in D. Keele, and E. Wever (eds.). New Firms and Regional Development in Europe (pp. 151-183). London: Croom Helm.

Orser, B. J., Hogarth-Scott, S., \& Riding, A. L. (2000). Performance, firm size, and management problem-solving. Journal of Small Business Management, 38(4), 42-58.

Raju, P. S., Lonial, S. C., \& Crum, M. D. (2011). Market orientation in the context of SMEs: A conceptual framework. Journal of Business Research, 64(12), 1320-1326. Available at: 10.1016/j.jbusres.2010.12.002.

Ramayah, M., Hafeez, T., \& Mohamad, A. (2016). The effect of market orientation as a mediating variable in the relationship between entrepreneurial orientation and SMEs performance. Nankai Business Review International Article Information, 33(2005), 233-246.

Rhee, J., Park, T., \& Lee, D. H. (2010). Drivers of innovativeness and performance for innovative SMEs in South Korea: Mediation of learning orientation. Technovation, 30(1), 65-75. Available at: https://doi.org/10.1016/j.technovation.2009.04.008.

Robbins, S. P., \& Coulter, M. (2002). Management. Upper Saddle River, NJ: Prentice-Hall.

Russell Merz, G., \& Sauber, M. H. (1995). Profiles of managerial activities in small firms. Strategic Management Journal, 16(7), 55 1-564. Available at: https://doi.org/10.1002/smj.4250160705.

Salim, I. M., \& Sulaiman, M. (2011). Organizational learning, innovation and performance: A study of Malaysian small and medium sized enterprises. International Journal of Business and Management, 6(12), 118-123. Available at: https://doi.org/10.5539/ijbm.v6n12p118.

Schalk, A. P., \& Gudlaugsson, T. (2009). Effects of market orientation on business performance: Empirical evidence from Iceland. Journal of the European Institute of Retailing and Services Studies, 6(9), 1-19.

Schermerhorn, J. R., Hunt, J. J. M., \& Osborn, R. N. (2002). Organizational behavior. New York: Wiley.

Smith, N., Bracker, J., \& Miner, J. (1987). Correlates of firms and entrepreneur on effectiveness of selling partner relationships. Journal of Marketing, 1, 3-17.

Sparrow, J., Tarkowski, K., Lancaster, N., \& Mooney, M. (2009). Evolving knowledge integration and absorptive capacity perspectives upon university-industry interaction within a university. Education + Training, 51(8/9), 648-664. Available at: $10.1108 / 00400910911005217$.

Srinivasan, R., Woo, C., \& Cooper, A. (1994). Performance determinants for male and female entrepreneurs: Krannert Graduate School of Management, Institute for Research in the.

Tan, M., \& Liu, Z. (2014). Paths to success: An ambidexterity perspective on how responsive and proactive market orientations affect SMEs' business performance. Journal of Strategic Marketing, 22(5), 420-441. Available at: https://doi.org/10.1080/0965254x.2013.876084.

Tomášková, E., \& Kopfová, A. (2010). Influence of strategic management on market orientation. Economics छ̊ Management.

Wales, W. J., Gupta, V. K., \& Mousa, F.-T. (2013). Empirical research on entrepreneurial orientation: An assessment and suggestions for future research. International Small Business Journal, 31(4), 357-383. Available at: https://doi.org/10.1177/0266242611418261.

Wang, C. L., \& Altinay, L. (2012). Social embeddedness, entrepreneurial orientation and firm growth in ethnic minority small businesses in the UK. International Small Business Journal, 30(1), 3-23. Available at: $10.1177 / 0266242610366060$

Webster, R. L., Hammond, K. L., \& Rothwell, J. C. (2014). Market orientation effects on business school performance: Views from inside and outside the business school. American Journal of Business Education, 7(1), 9-20. Available at: https://doi.org/10.19030/ajbe.v7i1.8315.

Yuchtman, E., \& Seashore, S. E. (1967). A system resource approach to organizational effectiveness. American Sociological Review, 32(6), 891-903. Available at: https://doi.org/10.2307/2092843.

Zahra, S. A., \& George, G. (2002). The net-enabled business innovation cycle and the evolution of dynamic capabilities. Information Systems Research, 13(2), 147-150. Available at: https://doi.org/10.1287/isre.13.2.147.90.

Zhang, J., \& Duan, Y. (2010). The impact of different types of market orientation on product innovation performance: Evidence from Chinese manufacturers. Management Decision, 48(6), 849-867. Available at: https://doi.org/10.1108/00251741011053433. 